\title{
Current practice of assessing students' sustainability competencies: a review of tools
}

\author{
Aaron Redman ${ }^{1,2,3}$ (D) Arnim Wiek ${ }^{1,2,3} \cdot$ Matthias Barth ${ }^{1,2,3}$
}

Received: 2 March 2020 / Accepted: 10 August 2020 / Published online: 1 September 2020

(c) The Author(s) 2020

\begin{abstract}
While there is growing agreement on the competencies sustainability professionals should possess as well as the pedagogies to develop them, the practice of assessing students' sustainability competencies is still in its infancy. Despite growing interest among researchers, there has not yet been a systematic review of how students' sustainability competencies are currently assessed. This review article responds to this need by examining what tools are currently used for assessing students' sustainability competencies to inform future practice. A systematic literature review was conducted for publications through the end of 2019, resulting in 75 relevant studies that detail the use of an assessment tool. We analyzed the described tools regarding their main features, strengths and weaknesses, as well as potential improvements. Based on this analysis, we first propose a typology of eight assessment tools, which fall into three meta-types: self-perceiving, observation, and test-based approaches, providing specific examples of practice for all tools. We then articulate strengths and weaknesses as well as potential improvements for each tool (type). This study structures the field of sustainability competency assessment, provides a criteria-based overview of the currently used tools, and highlights promising future developments. For the practice, it provides guidance to sustainability (science) instructors, researchers, and program directors who are interested in using competencies assessment tools in more informed ways.
\end{abstract}

Keywords Sustainability competencies $\cdot$ Assessment $\cdot$ Evaluation $\cdot$ Tools $\cdot$ Methods $\cdot$ Learning outcomes

\section{Introduction}

The world is in urgent need of competent professionals to contribute to societal transformations towards sustainability (Gordon et al. 2019), and educational institutions ought to prepare students for these roles (Barth 2016; Franco et al. 2019). In response to this challenge, there has been a

Handled by Tatsuya Kusakabe, Hiroshima University Center for the Study of International Cooperation in Education, Japan.

\footnotetext{
Aaron Redman

aaron.redman@asu.edu

1 Center for Global Sustainability and Cultural Transformation, Leuphana University of Lüneburg, Lüneburg, Germany

2 School of Sustainability, Arizona State University, Tempe, AZ, USA

3 Institute for Sustainable Development and Learning, Leuphana University of Lüneburg, Lüneburg, Germany
}

proliferation of sustainability science programs (O'Byrne et al. 2015), which increasingly define the learning objectives for their students in terms of sustainability competencies (Salovaara et al. 2020). Competencies are "complex combination[s] of knowledge, skills, understanding, values, attitudes and desire which lead to effective, embodied human action in the world" (Crick 2008). There is increasing agreement on the set of key competencies in sustainability (Redman et al. 2020), namely, systems-thinking, futures-thinking, values-thinking, strategic-thinking, and interpersonal competencies (Wiek et al. 2011)). Similarly, scholars and educators have started to converge on effective and efficient pedagogies to develop these competencies (Brundiers et al. 2010; Frisk and Larson 2011; Barth and Michelsen 2013).

Yet, the practice of assessing students' sustainability competencies is still in its infancy (Waltner et al. 2019). A broad range of assessment tools are currently in use for both research and instructional purposes (Cebrián Bernat et al. 2019). However, these tools are rarely selected with clear and informed intention, largely due to a lack of guidance in the literature (Besong and Holland 2015). Despite a 
growing body of research describing innovative pedagogies (Hallinger and Chatpinyakoop 2019), there is a shortage of empirical evidence of whether and in what ways these pedagogies are successful in developing students' sustainability competencies (Osagie et al. 2016; Mindt and Rieckmann 2017; Garrecht et al. 2018). Meanwhile, course instructors, curriculum designers, and program directors lack the means to effectively assess whether or not they are successfully educating sustainability professionals through their courses and programs, which is a core purpose of assessment (Kuh et al. 2014). This is a significant gap when it comes to constructive alignment (Biggs 1996) and putting all critical components of sustainability (science) education in place (Fig. 1). As this figure illustrates, reliable and valid tools for assessing competencies, which is the focus of this article, fulfill an important function in supporting structured teaching efforts and student learning for sustainability.

Education science researchers have called out traditional methods of assessment as inadequate for measuring multidimensional and performance-oriented competencies (Frey and Hartig 2009). Traditional assessments are already challenging for experts to create and apply properly (Reckase 2017) and adequate assessment of competencies even more so (Leutner et al. 2017). Nonetheless, much exploratory work on assessing competencies has begun (Hartig et al. 2007), though a review found that progress on competency assessment was limited, particularly in the non-cognitive dimensions (Zlatkin-Troitschanskaia et al. 2015). For sustainability competencies in particular, Barth (2009) provided a conceptual framing, and sporadic if increasing efforts to develop tools has been undertaken by individual instructors and researchers around the world (Cebrián Bernat et al. 2019). This growing body of research has yet to be brought together in a systematic review which compares the existing tools and provides guidance to instructors, researchers, and program directors.

This review article examines what tools are currently used for assessing students' sustainability competencies, as documented in the literature through the end of 2019. We conducted an in-depth analysis of a comprehensive sample of peer-reviewed publication $(N=75)$ and distilled a typology of assessment tools for sustainability competencies. We also evaluate strengths and weaknesses of these tools and offer avenues for improvements. The article provides guidance to instructors, researchers, and program directors who are interested in using competencies assessment tools in more informed ways.

\section{Research design}

To review literature on assessing students' sustainability competencies thus far, we systematically collected publications from SCOPUS, Web of Science, ERIC, and Google Scholar, published in English through 2019 resulting in a first pool of 3908 publications. Following Moher et al.'s (2009) and Fink's (2014) systematic review approaches, we then iteratively excluded publications by first reviewing the titles, then abstracts and finally the full text. This yielded 75 publications focused on sustainability competencies assessments (see appendix for a full description of procedures). For this sample, Fig. 2 shows the steady growth of publications on sustainability competencies assessments over the last 10 years. However, they still only represents less than $7 \%$ of the sustainability (science) education research field as reviewed in 2017 (Grosseck et al. 2019). The publications come from 35 outlets, yet, research took place almost exclusively in OECD countries (93\%) and at higher education
Fig. 1 Framework which indicates the crucial role assessment plays in supporting student learning

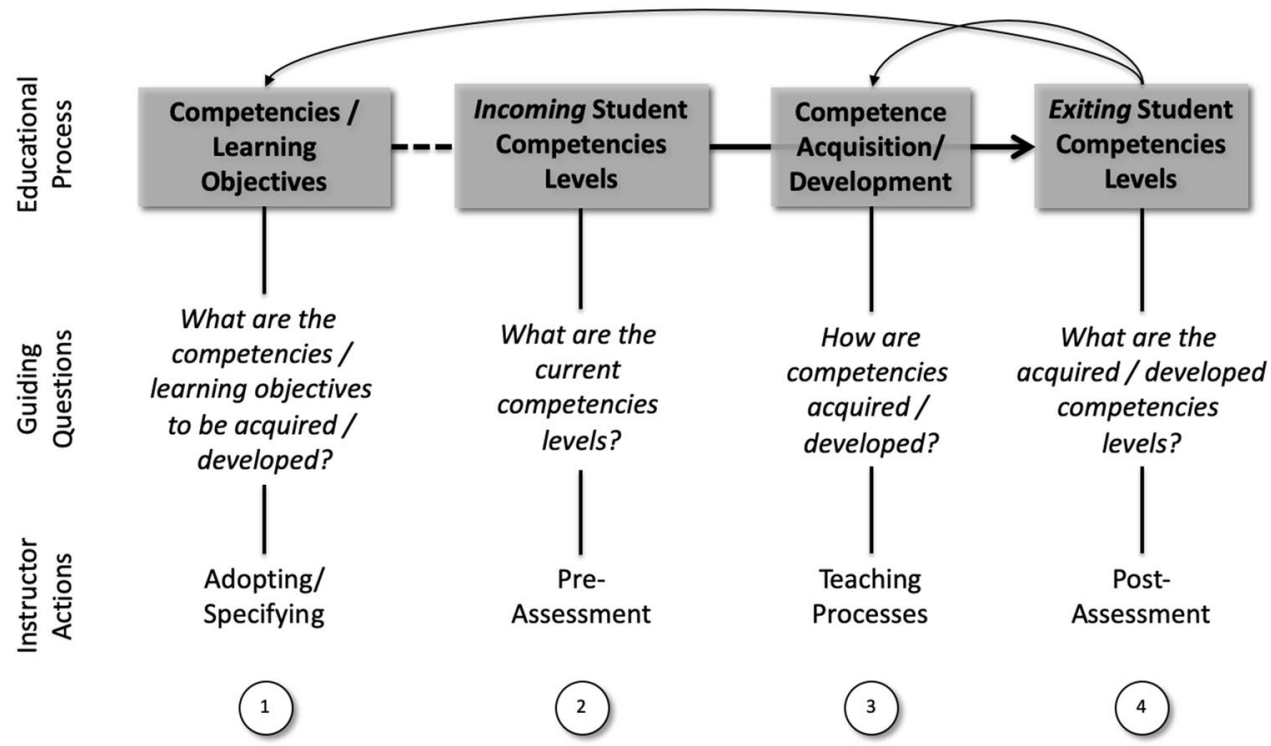




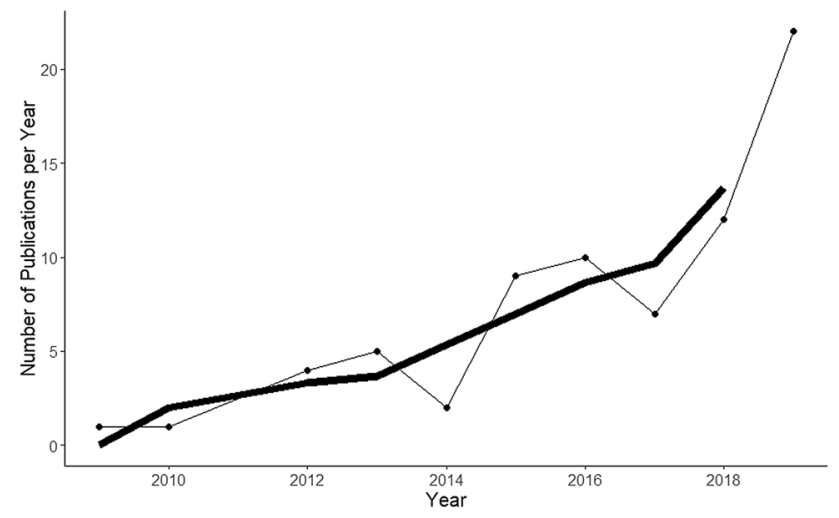

Fig. 2 Publications on sustainability competencies assessments per year in final sample (solid line is rolling 3-year average)

institutions (87\%). Sustainability/environmental degree programs, teacher training, general education, and business/ management education were the most frequent foci areas of the studies. Research on assessment in sustainability (science) education appears to likely be in its emergent growth phase, trailing the pattern of research growth in sustainability science by about 15 years (Fang et al. 2018).

In reviewing the sampled literature, we identified 121 total tools in use (many of the 75 reviewed studies used more than one tool), which we classified into eight distinct types of tools currently being used to assess students' sustainability competencies. To be clustered into a type, a tool has to have a record of several applications (with documentation). We disregarded terminological differences in cases, where authors used different names for the same tool. We first generalized the descriptions to cover all specific tools under each type and then standardized the descriptions to make the tools comparable (Table 1). We then analyzed each tool (type) independently and in contrast to each other using a set of common attributes (Table 2). We finally appraised strengths and weaknesses of each tool (type), as well as explored potential improvements (Table 3). This appraisal was informed by insights on competencies assessments gleaned from the broader educational literature.

\section{Typology of tools for competencies assessment}

Instructors use a wide variety of tools for assessing students' sustainability competencies (121 in total were identified from this sample). They can nonetheless be clustered into eight major tools (types) (Table 1), currently in use. Some of these types are quite broad (e.g., reflective writing), while others are narrower, but also more refined (e.g., concept mapping). Many studies used more than one tool $(n=31)$ with scaled self-assessment being disproportionately represented among these (80\%) when compared to the overall sample (56\%). Generally, there were only few cases, where a single tool was developed over multiple publications. The exception to that was the scenario/case test type, where four tools were iteratively developed over 14 publications.

We first present examples of each tool (Table 2). These examples were chosen based on three criteria: (1) representativeness of tool, (2) clarity of description in publication (a frequent deficiency), and (3) if they used the competency framework articulated by Wiek et al. (2011). We chose to purposefully select examples which use the same key competencies, so that comparability between tools is enhanced. In our sample, the Wiek et al. (2011) framework was the only one used across enough studies to make this possible, besides it being highly influential on the broader field of sustainability (science) education as noted in other reviews (Grosseck et al. 2019). However, it is not possible to conduct a comprehensive meta-analysis of assessment results due to the diversity of what is being assessed, i.e., the specific sustainability competencies targeted.

The examples are drawn from a single source for each tool. They are described by two sets of characteristics: one for the tool itself and one for its application. The table can

Table 1 Currently used tools for assessing students' sustainability competencies (with frequency)

\begin{tabular}{lll}
\hline Tool & Brief description & $N$ \\
\hline Scaled self-assessment & Students are asked to rate their own competency development based on a pre-determined scale & 42 \\
Reflective writing & Students respond in writing to prompts reflecting on their competency development & Students are presented with a case and asked to respond to specific competency-requiring prompts \\
Scenario/case test & Students respond to prompts verbally reflecting on their competency development & 16 \\
Focus group/interview & Students are evaluated for competency while carrying out course activities in or out of the classroom (e.g., & 11 \\
Performance observation & professional setting) & \\
Concept mapping & Students are given a prompt and asked to create a two-dimensional image with nodes and connections (spe- & 7 \\
Conventional test & cific to systems-thinking competence) & \\
Regular course work & Students take a test which may include multiple choices or short answers which are linked to competencies & 7 \\
\hline
\end{tabular}




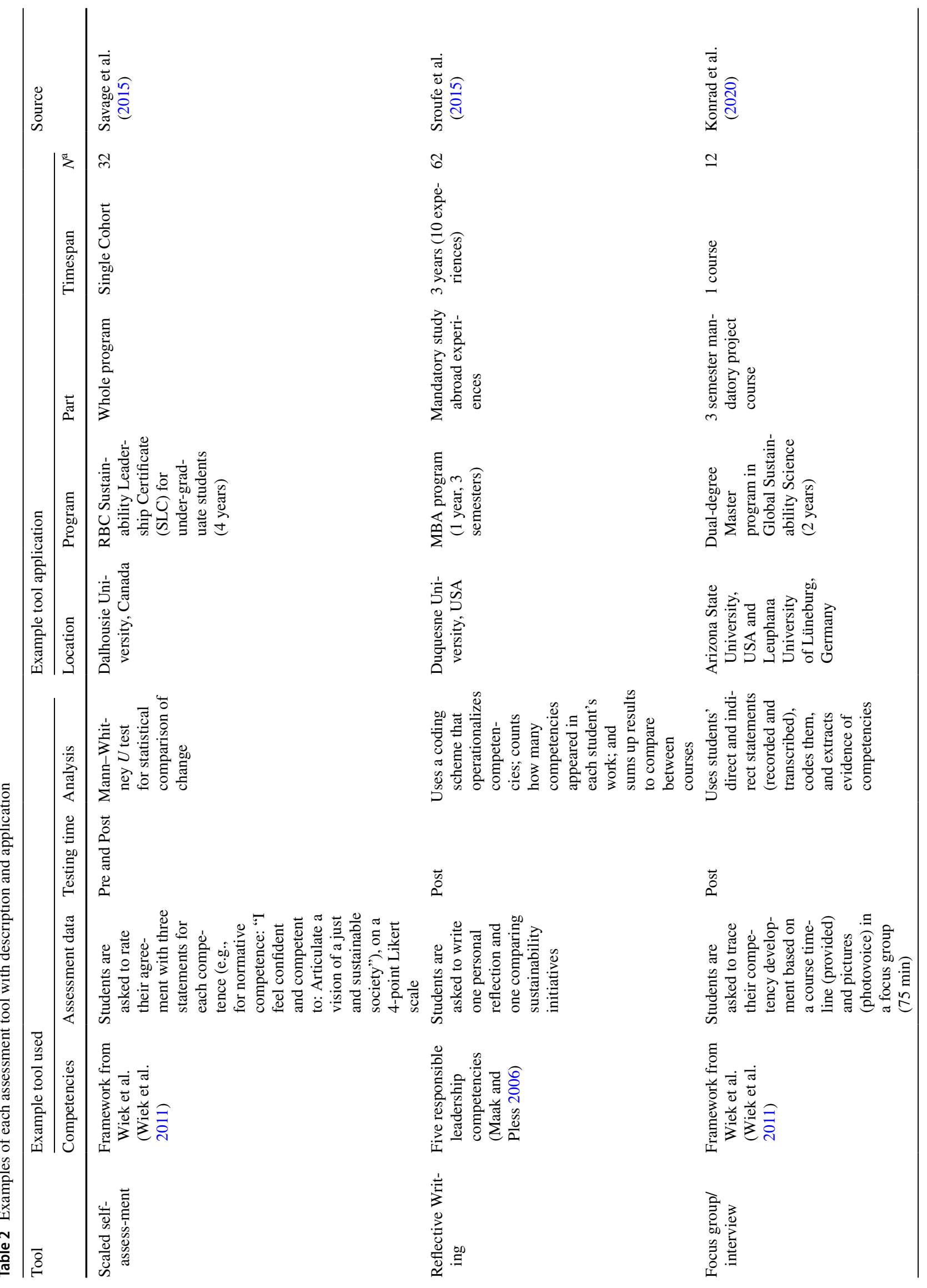




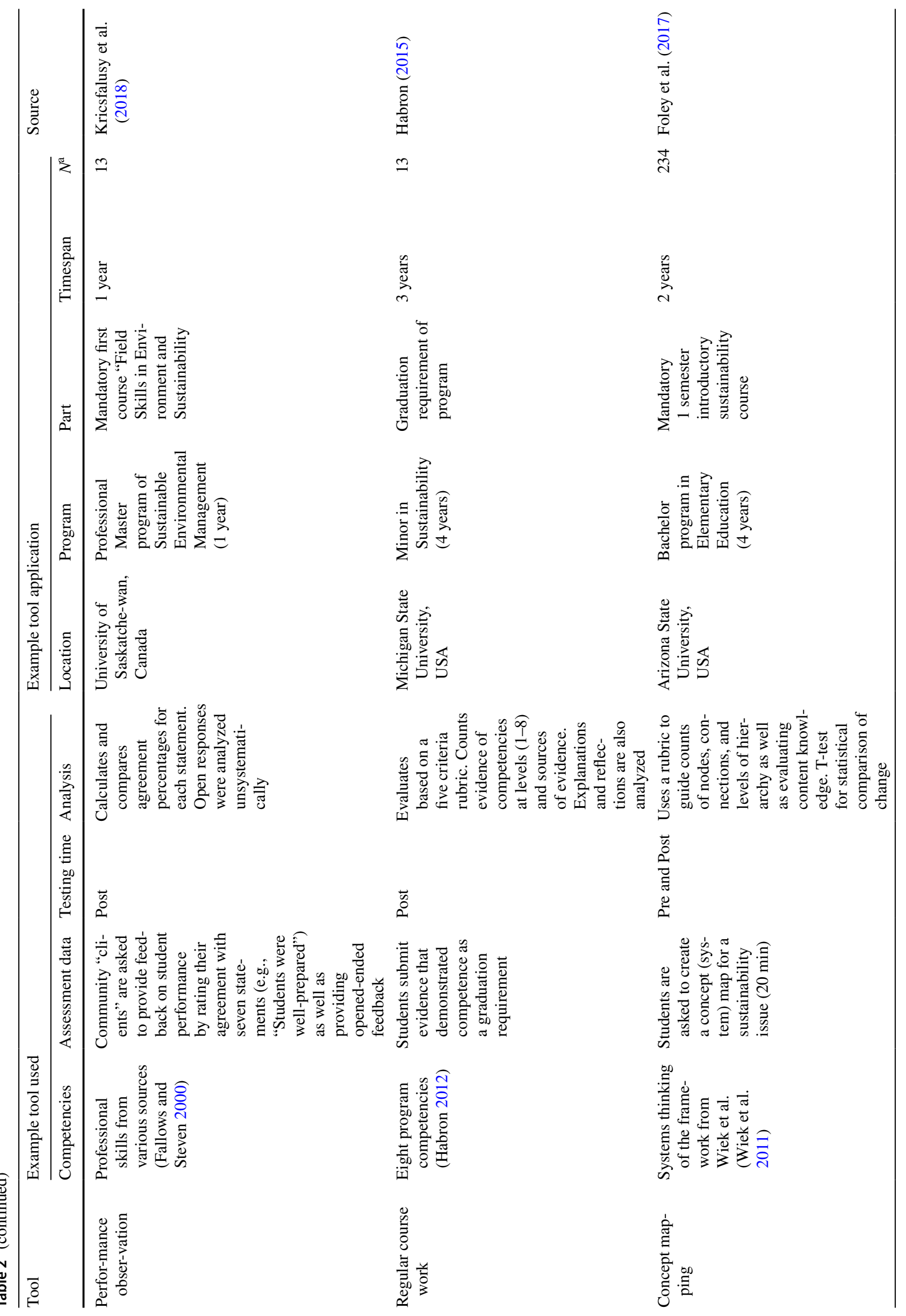




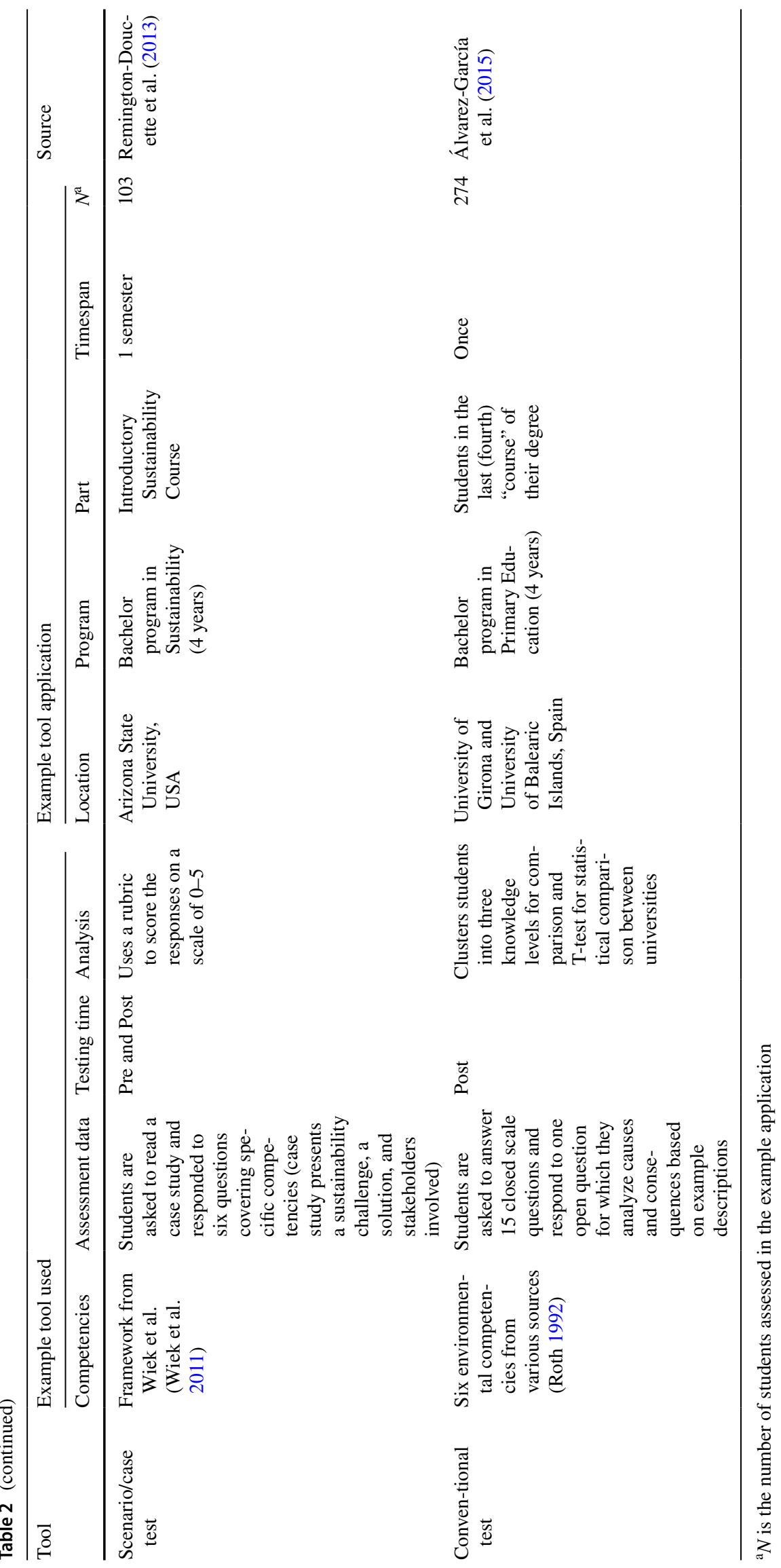




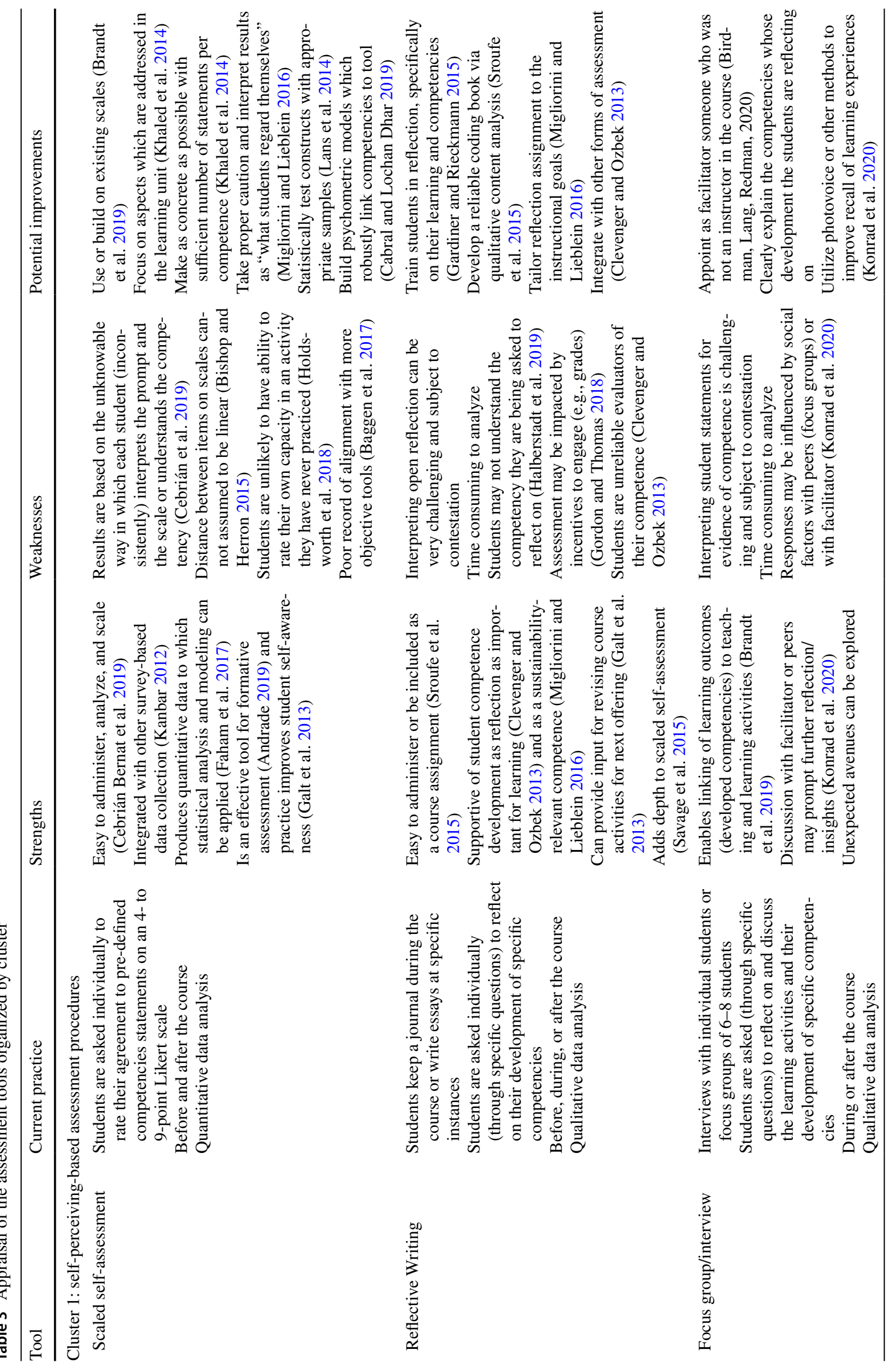




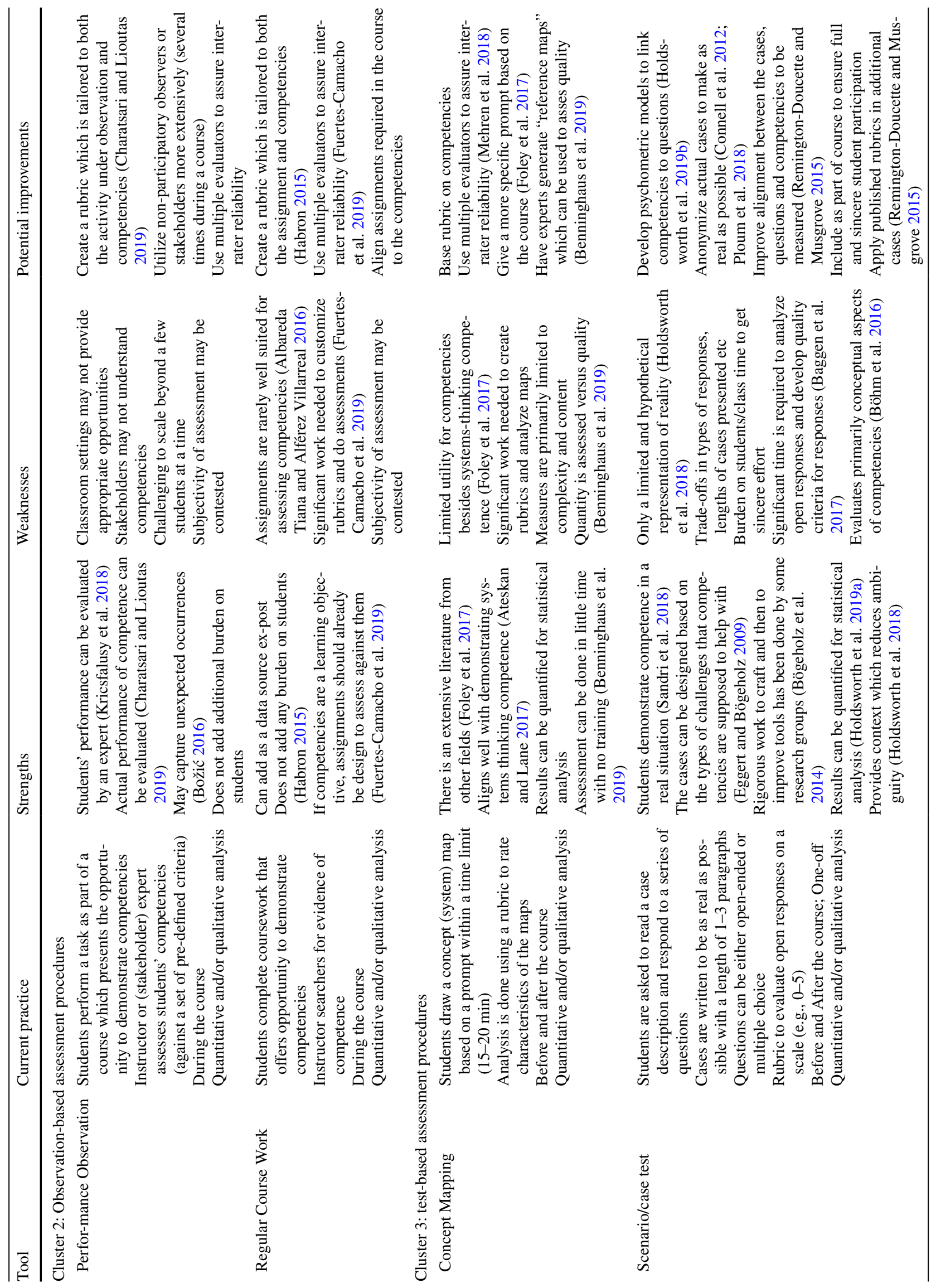




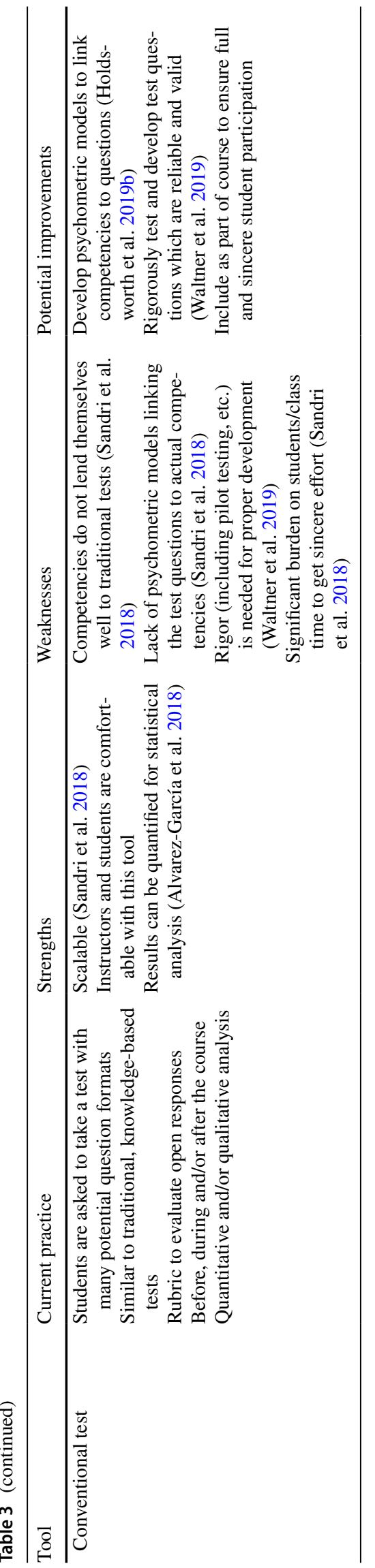

be read horizontally to give an overview of each example or vertically to enable comparison between tools for each characteristic. The different tools were each fairly widely applied (as represented by the captured characteristics). The scope of applications described in Table 2 well represents those within the overall sample. For each tool, there was also quite a variety of application settings.

Having identified eight distinct assessment tools (types), each of the studies (full list in the "Appendix") was reviewed again, particularly with respect to the research methods used, and an analysis for each tool conducted. The first result of this analysis was that the eight tools can be further clustered into three meta-types: self-perceiving-based assessment procedures, observation-based assessment procedures, and test-based assessment procedures (see Table 3). The critical characteristic of the tool which determines the cluster is who is doing the assessment of the students' competencies. For self-perceiving-based procedures (e.g., reflective writing), the student himself/herself is assessing his/her own competence level and/or development. In applying observation-based procedures, instructors or experts assess students' competencies. The test-based assessment procedures use a predefined set of criteria (or "correct" answers) to evaluate students' competencies. This distinction in who assesses students' competencies leads to the tools within each cluster sharing much in common in terms of strengths and weaknesses.

Based on the analysis of the sample articles and review of broader education science literature, we compiled a distilled set of strengths, weaknesses, and best practices for each tool (Table 3). An exemplary citation was provided for each point whenever possible, typically representing many other sources. The column on current practice in Table 3 offers a generic description of the tool based on the full scope of examples, in contrast to the detailed, but specific examples offered in Table 2.

\section{Discussion}

We conducted a systematic review of the growing body of published research on the assessment of sustainability competencies. This review identified a wide range of assessment tools currently in use (more than 120 specific tools). Yet, despite this diversity on the surface, we argue for a typology containing eight major tool types that can be further grouped into three clusters of assessment procedures (Table 3). The tool types we specify overlap meaningfully with those utilized by Nicolaou and Constantinou (2014) in their systematic review of assessing a competence closely related to sustainability (modeling in science). In-depth insights into the tools comes via the examples included in Table 2 and through the appraisal summarized in Table 3. 
There are clear signs of substantial investment in model and tool building (Waltner et al. 2019), multi-methodological triangulations (Kricsfalusy et al. 2018), and the piloting of innovative assessment tools (see box 1, below). However, this appraisal also reveals flaws in the current assessment practice in sustainability (science) education: there is too little connectivity across studies, in particular regarding agreement on outcomes; an over-reliance on scaled self-assessment; and general insufficiency of actual tool development. The implications of these flaws can be seen in Fig. 1-unclear learning objectives (1) or the lack of a baseline assessment (2) undermine the effectiveness of even well-developed assessment tools. et al. (2011), a handful of studies explicitly proposed "new" competencies such as sustainability and social responsibility (SSR) (Albareda Tiana and Alférez Villarreal 2016); others leave it quite unclear what competencies were actually being assessed (e.g., Azeiteiro et al. 2015). Apart from making comparisons across assessments impossible, this ambiguity of learning outcomes undermines recognition and career trajectories of graduates from sustainability (science) programs.

Scaled self-assessment was by far the most commonly chosen assessment tool (56\% of cases); yet, only rarely (Migliorini and Lieblein 2016) has the tool choice been

\begin{abstract}
Box 1. Novel assessment tools use in-vivo simulated professional situations to assess students' sustainability competencies following a model from medical and social work education programs. A recently published study (Foucrier \& Wiek, 2020) presents the results of testing such an assessment tool for an interdisciplinary graduate course in sustainability entrepreneurship at Arizona State University (several graduate programs involved). The students were provided with material and asked to prepare as sustainability consultants for a simulated city council meeting on infusing sustainability into the local economy. The tool was tested in two different settings, one deployed with four of the graduate students at the local city hall with actual professionals (city council member, local government administrator, local business association representative), and one with five of the graduate students at the university with "actors" (sustainability graduates and researchers). Student performances were evaluated against a set of 22 criteria. The test results indicate that the tool is valid/reliable against a number of these criteria and provided an assessment of student performance very close to actual practice. Such an in-vivo assessment proved both resource and time intensive, but there are guidelines under which conditions this assessment tool seems most effective and a worthy investment.
\end{abstract}

Other than the studies, where the same research group builds off of their previous work (scenario/case test type), there are no obvious connections (e.g., citations) made across research efforts. Even in the cases, where the same competencies are assessed (e.g., Wiek et al. 2011) and the same assessment tool is applied (e.g., scaled self-assessment), new studies are not building off the tool previously used (e.g., Molderez and Fonseca 2018). The reviewed competency-like constructs that are currently used in assessments are often so differently described that a comparison across assessments is impossible. Besides drawing on Wiek justified. In their descriptive review, Bernat et al. (2019) hypothesize that this type of tool is often selected, because "it is less time-consuming, easy to distribute amongst a larger number of students, and in turn it provides a larger amount of information." Several authors make the case for its pedagogical uses in sustainability science (Galt et al. 2013), in line with educational scholars who have advocated for self-reflection as a tool for formative assessment (Andrade 2019). However, as a tool of robust, reliable, and valid measurement of sustainability competencies, selfassessment falls much too short to warrant such popularity. 
As Metzler and Kurz (2018, p. 8) conclude in their report on educational assessment procedure, "data gleaned from easy measurement tell us little about the student learning that matters most."

Even among the assessment studies carefully selected for inclusion in this review, there is a tendency for development of assessment tools to be an apparent afterthought. The main topics of the studies are the pedagogical approach, case description, or programmatic innovation. Assessment as such is used to produce some empirical evidence to validate those initiatives' success. Little effort goes into tool development ahead of time or reflection afterwards. But there are many studies from the educational sciences (Barth and Michelsen 2013) that have rigorously developed assessment tools, which the practice of sustainability competencies assessment should adopt going forward. Some, such as the recent work of Mehren et al. (2018) are highly relevant (assessing systems thinking in geography), yet are not being learned from in sustainability science. We recommend four steps. First, developing a clear set of learning objectives/outcomes to be assessed, properly operationalized for the given context; second, providing a theoretical and empirical basis for selecting a particular assessment tool to be used; third, articulating a psychometric model which links the learning outcomes to the tool to be used; fourth, pilot testing the tool with a relevant sample population.

Many disciplines have adopted some form of sustainability (science) education and instructors ought to look for assessment tools to fit their specific teaching situation. The experiences so far suggest that combining assessment tools may be the best way to address the shortcomings of any particular assessment tool. For example, assessment tools with reasonable validity due to narrow learning objectives, e.g., (Bögeholz et al. 2014), will likely have low reliability across contexts and content (Schuwirth and Van Der Vleuten 2011). Each assessment tool has inherent weaknesses even with proper development (which the typology helps to foresee); thus, triangulation should happen on two levels - within the clusters and between them. For example, combining scaled self-assessment with reflective writing (within a cluster) provides a more complete and meaningful picture of the students' views of their own competencies, while triangulating these results with a testing approach (between clusters) checks the validity of students' self-perception against an objective (if typically narrower) measure.

As mentioned above, individual cases of developing assessment tools seem quite promising. Beyond just the increase in the quantity of publications, some tools have been developed with rigor, along the lines of the four steps outlined above (e.g., Waltner et al. 2019). Additionally, it is critical to plan for ultimate deployment on a scale sufficient to the needs of sustainability (science) education (Arima 2009), a topic that Holdsworth et al. (2019b) have explicitly grappled with over a series of articles. Yet, for all the innovation that sustainability (science) education purports to offer pedagogically, the field has so far little to offer in terms of assessment. Inspiration could be drawn from many other educational fields (Leutner et al. 2017), in particular from medical education, with its innovative approaches to competency assessment (Lockyer et al. 2017). This is in line with other intriguing parallels between medical and sustainability (science) education. The recent in-vivo assessment described in box 1 drew its inspiration from the long and established practice of competencies assessment in medical education. Sustainability (science) education researchers and practitioners would do well to find inspiration in such corners.

\section{Conclusions}

This article offers a typology which provides guidance for instructors, researchers, and program directors interested in assessing students' competencies in sustainability. This typology, based on a systematic review and synthesis of the academic literature through the end of 2019 , goes beyond description to offer an appraisal of eight types of assessment tools. The analysis of their strengths, weaknesses, and best practices distills the key lessons from the 75 peer-reviewed publications included.

Reflective of the rest of the field of sustainability (science) education, there is a lack of explicit agreement on what is being assessed. This makes comparison of results impossible but also challenges comparisons of the process of assessment (i.e., the tools themselves). Perhaps due to assessment not being the topic of primary research interest, the assessment tools are not typically well-developed and often inappropriately used. This is particularly true of scaled self-assessment, for which weaknesses are well documented, yet, continues to dominate current assessment practice. In response to the lack of robust assessment tools, many instructors, researchers, and program directors have chosen to apply more than one, an approach which is likely to have value even if utilizing tools with extensive development. The proposed typology provides a structure of the field as it is today. As more tools are being developed and refined, we would expect to distinguish more specific tools such as Concept Mapping (specific to systems-thinking competence) within each of the broader categories. Ultimately, it would be the meta-types (e.g., self-perceiving) which would form the critical organizing structure. Despite a bumpy beginning, current trends are quite positive, as more rigor is being applied in combination with meaningful innovations.

Considering the need for broad sustainability (science) education, efforts ought to be accelerated. If education is going to contribute to the needed global transformations, the scholarly community needs to generate more evidence 
about "what works" for teaching and learning (evidence-supported practices), and this requires robust assessment tools. As we briefly touched on, sustainability (science) education researchers need to draw much more heavily on work being done in other education research fields. These efforts should extend beyond just the research perspective to include coordination across the relevant parties. Researchers, for example, need to focus on linking outcomes to the actual learning processes, while instructors may emphasize the formative aspect, and program directors be concerned about objective and comparable measures for reporting. In these efforts, there is a need for innovative assessment approaches that more directly prepare students for their professional paths and the challenges they will be facing.

Acknowledgements The authors gratefully acknowledge funding from the Lower Saxony Ministry of Science and Culture and Volkswagen Foundation for the grant "Educating Future Change Agents-Higher Education as a Motor of the Sustainability Transformation" (A115235) through the program "Science for Sustainable Development". The authors would like to thank their colleagues Sarah Holdsworth and Orana Sandri from the Royal Melbourne Institute of Technology for comments on the manuscript's topic at various stages.

Funding Open Access funding provided by Projekt DEAL.

Open Access This article is licensed under a Creative Commons Attribution 4.0 International License, which permits use, sharing, adaptation, distribution and reproduction in any medium or format, as long as you give appropriate credit to the original author(s) and the source, provide a link to the Creative Commons licence, and indicate if changes were made. The images or other third party material in this article are included in the article's Creative Commons licence, unless indicated otherwise in a credit line to the material. If material is not included in the article's Creative Commons licence and your intended use is not permitted by statutory regulation or exceeds the permitted use, you will need to obtain permission directly from the copyright holder. To view a copy of this licence, visit http://creativecommons.org/licenses/by/4.0/.

\section{Appendix}

Synthesizing a growing body of research, such as that on sustainability competency assessment, is best done through a literature review (Snyder 2019). For this study, we conducted a literature review following the procedures laid out by Fink (2014). This appendix describes, how we followed Fink's (2014) approach to be systematic, explicit, comprehensive and reproducible. We sought to identify all articles that were published on assessing sustainability competencies. To be sure that definitional differences did not accidentally exclude relevant articles, we searched for synonyms of competencies and did not include assessment in the search procedures (it is used in many other ways in sustainability fields, e.g., LCA), rather using it as a screening criterion. We drew from as broad a pool of publications as possible, so we conducted our search on Web of Science, SCOPUS, ERIC, and Google Scholar. Based on other reviews, we expected these databases to provide comprehensive coverage. The following search strings were used:

a. Scopus

i. Search the title, abstract and keywords; English; Through 2019

ii. TITLE-ABS-KEY ("competency" OR "competence" OR "competencies" OR "competences" OR "attribute" OR "attributes" OR "capability" OR "capabilities" OR "learning outcome" OR "learning outcomes") AND TITLE-ABS-KEY ( education) AND KEY ( "sustainable development" OR "sustainability") AND LANGUAGE ( english) AND PUBYEAR $<2019$ AND ( EXCLUDE ( SUBJAREA, "MEDI") OR EXCLUDE ( SUBJAREA, "NURS") OR EXCLUDE ( SUBJAREA, "PHAR") OR EXCLUDE ( SUBJAREA, "HEAL") OR EXCLUDE ( SUBJAREA, "DENT") OR EXCLUDE ( SUBJAREA, "IMMU"))

iii. 1398 results

a. Web of Science

i. Topic search (TS); English; Through 2019

ii. TS $=(($ "competency" OR "competence" OR "competencies" OR "competences" OR "attribute" OR "attributes" OR "capability" OR "capabilities" OR "learning outcome" OR "learning outcomes") AND "education" AND ("sustainable development" OR "sustainability"))

iii. 1198 results

a. ERIC (proquest)

i. Search Anywhere; 2 separate command lines; English; Through 2019

ii. "competency" OR "competence" OR "competencies" OR "competences" OR "attribute" OR "attributes" OR "capability" OR "capabilities" OR "learning outcome" OR "learning outcomes" I "sustainable development" OR "sustainability"

iii. 830 results

a. Google Scholar- search

i. Used the software Harzing's Publish or Perish https ://harzing.com/resources/publish-or-perish which searches and downloads up to 1,000 citations but has a character limit on searches

ii. Through 2019| Sustainability, education ICompetencies: 750; Attributes: 250; Capabilities: 250; "Learning Outcomes": 250

iii. 1,000 results

After duplicates were removed, 3898 publications constituted the first sample. Following the structured review approaches of Moher et al. (2009) and Fink (2014), we then iteratively excluded publications. We excluded irrelevant publications first based on titles (1747), abstracts (1241) and other content (108). Of the remainder, the full text was downloaded (except for 52 which could not be) and reviewed 
for a final exclusion (559). A detailed reading of each article was carried out resulting in a few more exclusions (64) and a final sample of 75 articles. At the title stage, only the most obviously unfit publications were excluded. An example title to remove was: "What attributes do Australian midwifery leaders identify as essential to effectively manage a Midwifery Group Practice?" The abstracts and full text were given more than one critical reading to determine inclusion or exclusion. The selection of articles was carried out primarily by the first author, with checks done by the co-author. Other experts in the field were consulted for missing publications. The criteria used to include publications (i.e., not put them in the exclusion group at each step) were:
- Published or in-press by the end of 2019

- Education type (any level) of the following domains:

o Sustainability focused education

o Adding sustainability focus to other degrees/programs/general etc.

o Environmental education with a strong sustainability related focus

- Included specific learning objectives (e.g., competencies, capabilities, learning outcomes, attributes)

- Includes an evaluation or assessment of impact of a program on learning objectives

See Table 4.

- English

Table 4 Publications which used each tool type

Tool $\quad N \quad$ Publications using the tool

Scaled self- 42 Albareda Tiana S, Alférez Villarreal A (2016) A collaborative programme in sustainability and social responsibility. Int J Sustain High Educ 17:719-736. assess- $\quad$ https://doi.org/10.1108/IJSHE-07-2016-0134

ment Alvarez-García O, Sureda-Negre J, Comas-Forgas R (2018) Assessing environmental competencies of primary education pre-service teachers in Spain. Int J Sustain High Educ 19:15-31. https://doi.org/10.1108/IJSHE-12-2016-0227

Anderson EL (2015) Developing key sustainability competencies through real-world learning experiences: evaluating community environmental services. search.proquest.com

Ateskan A, Lane JF (2018) Assessing teachers' systems thinking skills during a professional development program in Turkey. J Clean Prod 172:4348-4356. https://doi.org/10.1016/j.jclepro.2017.05.094

Azeiteiro UM, Bacelar-Nicolau P, Caetano FJPP, Caeiro S (2015) Education for sustainable development through e-learning in higher education: experiences from Portugal. J Clean Prod 106:308-319. https://doi.org/10.1016/j.jclepro.2014.11.056

Baggen Y, Kampen JK, Naia A, et al. (2017) Development and application of the opportunity identification competence assessment test (OICAT) in higher education. Innov Educ Teach Int 55:1-11. https://doi.org/10.1080/14703297.2017.1348962

Besong F, Holland C (2015) The Dispositions, Abilities and Behaviours (Dab) Framework for profiling learners' sustainability competencies in higher education. J Teach Educ Sustain 17:5-22. https://doi.org/10.1515/jtes-2015-0001

Biasutti M, Surian A (2012) The students' survey of education for sustainable development competencies: a comparison among faculties. Discourse Commun Sustain Educ 3:75-82. https://doi.org/10.2478/v10230-012-0005-y

Božić M (2016) Competence development in a project and problem based learning professional practice module in engineering education based on illstructured problem. ddd.uab.cat

Brandt J-O, Bürgener L, Barth M, Redman A (2019) Becoming a competent teacher in education for sustainable development. Int J Sustain High Educ 20:630-653. https://doi.org/10.1108/IJSHE-10-2018-0183

Brassler M, Dettmers J (2017) How to enhance interdisciplinary competence-interdisciplinary problem-based learning versus interdisciplinary projectbased learning. Interdiscip J Probl Learn 11:15. https://doi.org/10.7771/1541-5015.1686

Cabral C, Lochan Dhar R (2019) Green competencies: construct development and measurement validation. J Clean Prod 235:887-900. https://doi. org/10.1016/j.jclepro.2019.07.014

Cazorla-Montero, de los Ríos-Carmenado, Pasten (2019) Sustainable development planning: master's based on a project-based learning approach. Sustainability 11:6384. https://doi.org/10.3390/su11226384

Cebrián G, Pascual D, Moraleda Á (2019) Perception of sustainability competencies amongst Spanish pre-service secondary school teachers. Int J Sustain High Educ 20:1171-1190. https://doi.org/10.1108/IJSHE-10-2018-0168

Ceulemans G, Severijns N (2019) Challenges and benefits of student sustainability research projects in view of education for sustainability. Int J Sustain High Educ 20:482-499. https://doi.org/10.1108/IJSHE-02-2019-0051

Clevenger CM, Ozbek ME (2013) Service-learning assessment: sustainability competencies in construction education. J Constr Eng Manag 139:A4013010. https://doi.org/10.1061/(ASCE)CO.1943-7862.0000769

Faham E, Rezvanfar A, Movahed Mohammadi SH, Rajabi Nohooji M (2017) Using system dynamics to develop education for sustainable development in higher education with the emphasis on the sustainability competencies of students. Technol Forecast Soc Change 123:307-326. https://doi.org/10.1016/j. techfore.2016.03.023

Fuertes-Camacho M, Graell-Martín M, Fuentes-Loss M, Balaguer-Fàbregas M (2019) integrating sustainability into higher education curricula through the project method, a global learning strategy. Sustainability 11:767. https://doi.org/10.3390/su11030767

Galt RE, Parr D, Jagannath J (2013) Facilitating competency development in sustainable agriculture and food systems education: a self-assessment approach. Int J Agric Sustain 11:69-88. https://doi.org/10.1080/14735903.2012.683569

Gosselin D, Cooper S, Bonnstetter RJ, Bonnstetter BJ (2013) Exploring the assessment of twenty-first century professional competencies of undergraduate students in environmental studies through a business-academic partnership. J Environ Stud Sci 3:359-368. https://doi.org/10.1007/s13412-013-0140-1

Gosselin D, Cooper S, Lawton S, et al. (2016) Lowering the walls and crossing boundaries: applications of experiential learning to teaching collaboration. J Environ Stud Sci 6:324-335. https://doi.org/10.1007/s13412-015-0312-2

Hilser S (2016) Key competencies to action: transdisciplinary learning of key competencies for sustainability. lup.lub.lu.se

Kanbar N (2012) Can education for sustainable development address challenges in the Arab region? Examining business students' attitudes and competences on education for sustainable development: a case study. Discourse Commun Sustain Educ 3:41-62. https://doi.org/10.2478/v10230-012-0003-0

Kricsfalusy V, George C, Reed MG (2018) Integrating problem- and project-based learning opportunities: assessing outcomes of a field course in environment and sustainability. Environ Educ Res 24:593-610. https://doi.org/10.1080/13504622.2016.1269874

Lans T, Blok V, Wesselink R (2014) Learning apart and together: towards an integrated competence framework for sustainable entrepreneurship in higher education. J Clean Prod 62:37-47. https://doi.org/10.1016/j.jclepro.2013.03.036 
Table 4 (continued)

Tool $\quad N \quad$ Publications using the tool

Lengieza ML, Hunt CA, Swim JK (2019) Travel-induced learning: a validation of the sustainability insight scale. Curr Issues Tour 0:1-4. https://doi. org/10.1080/13683500.2019.1584160

MacDonald L, Shriberg M (2016) Sustainability leadership programs in higher education: alumni outcomes and impacts. J Environ Stud Sci 6:360-370. https://doi.org/10.1007/s13412-015-0344-7

Meza Rios MM, Herremans IM, Wallace JE, et al. (2018) Strengthening sustainability leadership competencies through university internships. Int J Sustain High Educ 19:739-755. https://doi.org/10.1108/IJSHE-06-2017-0097

Migliorini P, Lieblein G (2016) Facilitating transformation and competence development in sustainable agriculture university education: an experiential and action oriented approach. Sustainability $8: 1-15$. https://doi.org/10.3390/su8121243

Molderez I, Fonseca E (2018) The efficacy of real-world experiences and service learning for fostering competences for sustainable development in higher education. J Clean Prod 172:4397-4410. https://doi.org/10.1016/j.jclepro.2017.04.062

Osagie ER, Wesselink R, Runhaar P, Mulder M (2017) Unraveling the competence development of corporate social responsibility leaders: the importance of peer learning, learning goal orientation, and learning climate. J Bus Ethics. https://doi.org/10.1007/s10551-017-3638-8

Ploum L, Blok V, Lans T, Omta O (2019) Educating for self-interest or -transcendence? An empirical approach to investigating the role of moral competencies in opportunity recognition for sustainable development. Bus Ethics 28:243-260. https://doi.org/10.1111/beer.12214

Ploum L, Blok V, Lans T, Omta O (2018) Toward a validated competence framework for sustainable entrepreneurship. Organ Environ 31:113-132. https:// doi.org/10.1177/1086026617697039

Ploum L, Blok V, Lans T, Omta O (2018) Exploring the relation between individual moral antecedents and entrepreneurial opportunity recognition for sustainable development. J Clean Prod 172:1582-1591. https://doi.org/10.1016/j.jclepro.2017.10.296

Roy SG, de Souza SP, McGreavy B, et al. (2019) Evaluating core competencies and learning outcomes for training the next generation of sustainability researchers. Sustain Sci. https://doi.org/10.1007/s11625-019-00707-7

San Carlos Arce RO, Yoshida Y, Kudo S (2017) Fostering the next generation of sustainability professionals-assessing field-based courses in a sustainability science graduate program. Challenges Sustain 5:52-61. https://doi.org/10.12924/cis2017.05010052

San Carlos RO, Tyunina O, Yoshida Y, et al. (2016) Assessment of fieldwork methodologies for educational purposes in sustainability science: exercise on resilience, Tohoku Unit 2015. In: Sustainability science: field methods and exercises. Springer International Publishing, Cham, pp 67-91

Sánchez-Hernández, Maldonado-Briegas (2019) Sustainable entrepreneurial culture programs promoting social responsibility: a European regional experience. Sustainability 11:3625. https://doi.org/10.3390/su11133625

Savage E, Tapics T, Evarts J, et al. (2015) Experiential learning for sustainability leadership in higher education. Int J Sustain High Educ 16:692-705. https ://doi.org/10.1108/IJSHE-10-2013-0132

Stock T, Kohl H (2018) Perspectives for international engineering education. Procedia Manuf 21:10-17. https://doi.org/10.1016/j.promfg.2018.02.089

Weijs R, Bekebrede G, Nikolic I (2016) Sustainable competence development of business students: effectiveness of using serious games. Springer

Zemler L (2016) The convergence of societal advancement and the education of future sustainability professionals : a solution-oriented approach to placebased environmental challenges

Reflective writing

17 Albareda Tiana S, Alférez Villarreal A (2016) A collaborative programme in sustainability and social responsibility. Int J Sustain High Educ 17:719-736. https://doi.org/10.1108/IJSHE-07-2016-0134

Anderson EL (2015) Developing key sustainability competencies through real-world learning experiences: evaluating community environmental services. search.proquest.com

Azeiteiro UM, Bacelar-Nicolau P, Caetano FJPP, Caeiro S (2015) Education for sustainable development through e-learning in higher education: experiences from Portugal. J Clean Prod 106:308-319. https://doi.org/10.1016/j.jclepro.2014.11.056

Božić M (2016) Competence development in a project and problem based learning professional practice module in engineering education based on illstructured problem. ddd.uab.cat

Ceulemans G, Severijns N (2019) Challenges and benefits of student sustainability research projects in view of education for sustainability. Int J Sustain High Educ 20:482-499. https://doi.org/10.1108/IJSHE-02-2019-0051

Clevenger CM, Ozbek ME (2013) Service-learning assessment: sustainability competencies in construction education. J Constr Eng Manag 139:A4013010. https://doi.org/10.1061/(ASCE)CO.1943-7862.0000769

Galt RE, Parr D, Jagannath J (2013) Facilitating competency development in sustainable agriculture and food systems education: a self-assessment approach. Int J Agric Sustain 11:69-88. https://doi.org/10.1080/14735903.2012.683569

Gardiner S, Rieckmann M (2015) Pedagogies of preparedness: use of reflective journals in the operationalisation and development of anticipatory competence. Sustainability 7:10,554-10,575. https://doi.org/10.3390/su70810554

Gordon S, Thomas I (2018) 'The learning sticks': reflections on a case study of role-playing for sustainability. Environ Educ Res 24:172-190. https://doi. org/10.1080/13504622.2016.1190959

Halberstadt J, Timm J-M, Kraus S, Gundolf K (2019) Skills and knowledge management in higher education: how service learning can contribute to social entrepreneurial competence development. J Knowl Manag 23:1925-1948. https://doi.org/10.1108/JKM-12-2018-0744

Kricsfalusy V, George C, Reed MG (2018) Integrating problem- and project-based learning opportunities: assessing outcomes of a field course in environment and sustainability. Environ Educ Res 24:593-610. https://doi.org/10.1080/13504622.2016.1269874

Meza Rios MM, Herremans IM, Wallace JE, et al. (2018) Strengthening sustainability leadership competencies through university internships. Int J Sustain High Educ 19:739-755. https://doi.org/10.1108/IJSHE-06-2017-0097

Migliorini P, Lieblein G (2016) Facilitating transformation and competence development in sustainable agriculture university education: an experiential and action oriented approach. Sustainability 8:1-15. https://doi.org/10.3390/su8121243

Roy SG, de Souza SP, McGreavy B, et al. (2019) Evaluating core competencies and learning outcomes for training the next generation of sustainability researchers. Sustain Sci. https://doi.org/10.1007/s11625-019-00707-7

Savage E, Tapics T, Evarts J, et al. (2015) Experiential Learning for sustainability leadership in higher education. Int J Sustain High Educ 16:692-705. https ://doi.org/10.1108/IJSHE-10-2013-0132

Soini K, Korhonen-Kurki K, Asikainen H (2019) Transactional learning and sustainability co-creation in a university—business collaboration. Int J Sustain High Educ 20:965-984. https://doi.org/10.1108/IJSHE-11-2018-0215

Sroufe R, Sivasubramaniam N, Ramos D, Saiia D (2015) Aligning the PRME. J Manag Educ 39:244-275. https://doi.org/10.1177/1052562914560795 
Table 4 (continued)

\begin{tabular}{|c|c|c|}
\hline Tool & $N$ & Publications using the tool \\
\hline $\begin{array}{l}\text { Scenario/ } \\
\text { Case Test }\end{array}$ & 16 & $\begin{array}{l}\text { Baggen Y, Kampen JK, Naia A, et al. (2017) Development and application of the opportunity identification competence assessment test (OICAT) in higher } \\
\text { education. Innov Educ Teach Int 55:1-11. https://doi.org/10.1080/14703297.2017.1348962 }\end{array}$ \\
\hline
\end{tabular}
Math Sci Technol Educ 10:231-248. https://doi.org/10.12973/eurasia.2014.1079a

Böhm M, Eggert S, Barkmann J, Bögeholz S (2016) Evaluating sustainable development solutions quantitatively: competence modelling for GCE and ESD. Citizensh Soc Econ Educ 15:190-211. https://doi.org/10.1177/2047173417695274

Brandt J-O, Bürgener L, Barth M, Redman A (2019) Becoming a competent teacher in education for sustainable development. Int J Sustain High Educ 20:630-653. https://doi.org/10.1108/IJSHE-10-2018-0183

Connell KH, Remington S, Armstrong C (2012) Assessing systems thinking skills in two undergraduate sustainability courses: a comparison of teaching strategies. J Sustain Educ 3:

Eggert S, Bögeholz S (2009) Students' use of decision-making strategies with regard to socioscientific issues: an application of the rasch partial credit model. Sci Educ 94:230-258. https://doi.org/10.1002/sce.20358

Gresch H, Bögeholz S (2013) Identifying non-sustainable courses of action: a prerequisite for decision-making in education for sustainable development. Res Sci Educ 43:733-754. https://doi.org/10.1007/s11165-012-9287-0

Holdsworth S, Sandri O, Thomas I, et al. (2019) The assessment of graduate sustainability attributes in the workplace: Potential advantages of using the theory of planned behaviour (TPB). J Clean Prod 238:117,929. https://doi.org/10.1016/j.jclepro.2019.117929

Holdsworth S, Sandri O, Thomas I, et al. (2019) The use of the theory of planned behaviour to assess graduate attributes for sustainability. Environ Educ Res 1-21. https://doi.org/10.1080/13504622.2019.1700218

Holdsworth S, Thomas I, Sandri O (2018) Assessing graduate sustainability attributes using a vignette/scenario approach. J Educ Sustain Dev 12:120-139. https://doi.org/http://dx.doi.org/10.1177/0973408218792127

Holdsworth S, Thomas I, Sandri O, et al. (2017) Producing sustainability professionals: assessing graduate attributes in sustainability. researchbank.rmit. edu.au

Holdsworth S, Thomas I, Wong P, et al. (2019) Graduate attribute for minimising environmental harm—assessing effectiveness in the graduates' workplaces. J Clean Prod 211:396-407. https://doi.org/10.1016/j.jclepro.2018.11.169

Ploum L, Blok V, Lans T, Omta O (2019) Educating for self-interest or -transcendence? An empirical approach to investigating the role of moral competencies in opportunity recognition for sustainable development. Bus Ethics 28:243-260. https://doi.org/10.1111/beer.12214

Ploum L, Blok V, Lans T, Omta O (2018) Exploring the relation between individual moral antecedents and entrepreneurial opportunity recognition for sustainable development. J Clean Prod 172:1582-1591. https://doi.org/10.1016/j.jclepro.2017.10.296

Remington-Doucette SM, Hiller Connell KY, Armstrong CM, Musgrove SL (2013) Assessing sustainability education in a transdisciplinary undergraduate course focused on real-world problem solving. Int J Sustain High Educ 14:404-433. https://doi.org/10.1108/IJSHE-01-2012-0001

Remington-Doucette S, Musgrove S (2015) Variation in sustainability competency development according to age, gender, and disciplinary affiliation. Int J Sustain High Educ 16:537-575. https://doi.org/10.1108/IJSHE-01-2013-0005

15 Brandt J-O, Bürgener L, Barth M, Redman A (2019) Becoming a competent teacher in education for sustainable development. Int J Sustain High Educ 20:630-653. https://doi.org/10.1108/IJSHE-10-2018-0183

Cazorla-Montero, de los Ríos-Carmenado, Pasten (2019) Sustainable development planning: master's based on a project-based learning approach. Sustainability 11:6384. https://doi.org/10.3390/su11226384

Dai Y, Hwang S-H (2019) Technique, creativity, and sustainability of bamboo craft courses: teaching educational practices for sustainable development. Sustainability 11:2487. https://doi.org/10.3390/su11092487

Feriver Ş, Olgan R, Teksöz G, Barth M (2019) Systems thinking skills of preschool children in early childhood education contexts from Turkey and Germany. Sustainability 11:1478. https://doi.org/10.3390/su11051478

Gardiner S, Rieckmann M (2015) Pedagogies of preparedness: use of reflective journals in the operationalisation and development of anticipatory competence. Sustainability 7:10,554-10,575. https://doi.org/10.3390/su70810554

Habron G, Goralnik L, Thorp L (2012) Embracing the learning paradigm to foster systems thinking. Int J Sustain High Educ 13:378-393. https://doi. org/10.1108/14676371211262326

Halberstadt J, Timm J-M, Kraus S, Gundolf K (2019) Skills and knowledge management in higher education: how service learning can contribute to social entrepreneurial competence development. J Knowl Manag 23:1925-1948. https://doi.org/10.1108/JKM-12-2018-0744

Hilser S (2016) Key competencies to action: transdisciplinary learning of key competencies for sustainability. lup.lub.lu.se

Kieu TK, Singer J (2017) Involvement of NGOs in Training Teachers In Education For Sustainable Development in Vietnam: A Case Study. Eur J Sustain Dev 6:153-166. https://doi.org/10.14207/ejsd.2017.v6n1p153

Konrad T, Wiek A, Barth M (2020) Embracing conflicts for interpersonal competence development in project-based sustainability courses. Int J Sustain High Educ 21:76-96. https://doi.org/10.1108/IJSHE-06-2019-0190

Lambrechts W, Gelderman CJ, Semeijn J, Verhoeven E (2019) The role of individual sustainability competences in eco-design building projects. J Clean Prod 208:1631-1641. https://doi.org/10.1016/j.jclepro.2018.10.084

Migliorini P, Lieblein G (2016) Facilitating transformation and competence development in sustainable agriculture university education: an experiential and action oriented approach. Sustainability $8: 1-15$. https://doi.org/10.3390/su8121243

Molderez I, Fonseca E (2018) The efficacy of real-world experiences and service learning for fostering competences for sustainable development in higher education. J Clean Prod 172:4397-4410. https://doi.org/10.1016/j.jclepro.2017.04.062

Soini K, Korhonen-Kurki K, Asikainen H (2019) Transactional learning and sustainability co-creation in a university - business collaboration. Int J Sustain High Educ 20:965-984. https://doi.org/10.1108/IJSHE-11-2018-0215

Zemler L (2016) The convergence of societal advancement and the education of future sustainability professionals: a solution-oriented approach to placebased environmental challenges 
Table 4 (continued)

\begin{tabular}{|c|c|c|}
\hline Tool & $N$ & Publications using the tool \\
\hline sservation & 11 & 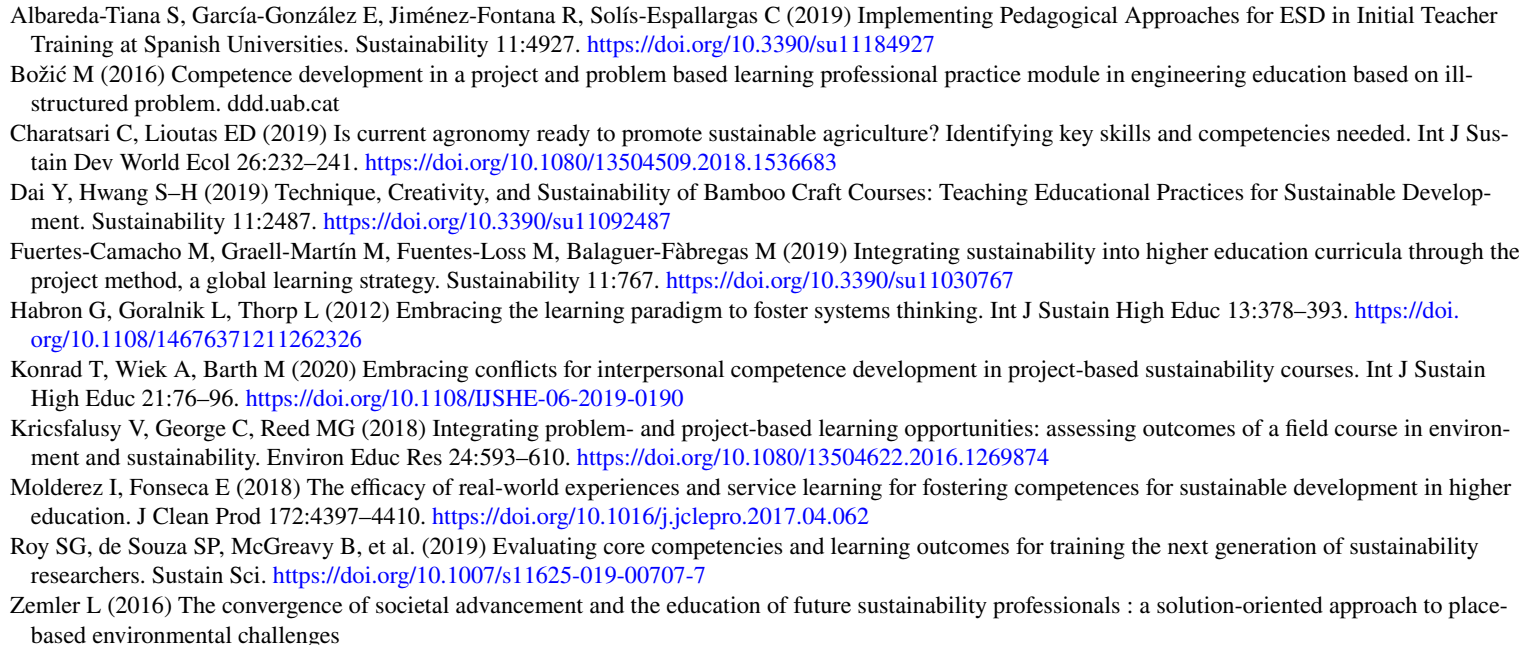 \\
\hline
\end{tabular}

Concept 7 Ateskan A, Lane JF (2018) Assessing teachers' systems thinking skills during a professional development program in Turkey. J Clean Prod 172:4348-4356. Mapping https://doi.org/10.1016/j.jclepro.2017.05.094

Benninghaus J, Mühling A, Kremer K, Sprenger S (2019) Complexity in education for sustainable consumption-an educational data mining approach using mysteries. Sustainability 11:722. https://doi.org/10.3390/su11030722

Clevenger CM, Ozbek ME (2013) Service-learning assessment: sustainability competencies in construction education. J Constr Eng Manag 139:A4013010. https://doi.org/10.1061/(ASCE)CO.1943-7862.0000769

Foley RW, Archambault LM, Hale AE, Dong H-K (2017) Learning outcomes in sustainability education among future elementary school teachers. J Educ Sustain Dev 11:33-51. https://doi.org/http://dx.doi.org/10.1177/0973408217725861

Habron G, Goralnik L, Thorp L (2012) Embracing the learning paradigm to foster systems thinking. Int J Sustain High Educ 13:378-393. https://doi. org/10.1108/14676371211262326

Segalàs J, Ferrer-Balas D, Mulder KF (2010) What do engineering students learn in sustainability courses? The effect of the pedagogical approach. J Clean Prod 18:275-284. https://doi.org/10.1016/j.jclepro.2009.09.012

Warren E, Foley R, Archambault L (2015) Building sustainability literacy among preservice teachers: An initial evaluation of a sustainability courses designed for K-8 educator. In: Educating science teachers for sustainability. pp 49-67

Test (other) 7 Alvarez-García O, Sureda-Negre J, Comas-Forgas R (2018) Assessing environmental competencies of primary education pre-service teachers in Spain. Int J Sustain High Educ 19:15-31. https://doi.org/10.1108/IJSHE-12-2016-0227

Brandt J-O, Bürgener L, Barth M, Redman A (2019) Becoming a competent teacher in education for sustainable development. Int J Sustain High Educ 20:630-653. https://doi.org/10.1108/IJSHE-10-2018-0183

Habron G, Goralnik L, Thorp L (2012) Embracing the learning paradigm to foster systems thinking. Int J Sustain High Educ 13:378-393. https://doi. org/10.1108/14676371211262326

Sandri O, Holdsworth S, Thomas I (2018) Vignette question design for the assessment of graduate sustainability learning outcomes. Environ Educ Res 24:406-426. https://doi.org/10.1080/13504622.2016.1263280

Schuler S, Fanta D, Rosenkraenzer F, Riess W (2018) Systems thinking within the scope of education for sustainable development (ESD)—a heuristic competence model as a basis for (science) teacher education. J Geogr High Educ 42:192-204. https://doi.org/10.1080/03098265.2017.1339264

Waltner E-M, Rieß W, Mischo C (2019) Development and validation of an instrument for measuring student sustainability competencies. Sustainability 11:1-20. https://doi.org/10.3390/su11061717

Weijs R, Bekebrede G, Nikolic I (2016) Sustainable Competence Development of Business Students: Effectiveness of Using Serious Games. Springer

Assess 6 Albareda Tiana S, Alférez Villarreal A (2016) A collaborative programme in sustainability and social responsibility. Int J Sustain High Educ 17:719-736. Assign- $\quad$ https://doi.org/10.1108/IJSHE-07-2016-0134

ments

Fuertes-Camacho M, Graell-Martín M, Fuentes-Loss M, Balaguer-Fàbregas M (2019) Integrating sustainability into higher education curricula through the project method, a global learning strategy. Sustainability 11:767. https://doi.org/10.3390/su11030767

Habron G (2015) Integrating ePortfolios into sustainability education. Int J ePortfolio 5:123-134

Habron G, Goralnik L, Thorp L (2012) Embracing the learning paradigm to foster systems thinking. Int J Sustain High Educ 13:378-393. https://doi. org/10.1108/14676371211262326

Roy SG, de Souza SP, McGreavy B, et al. (2019) Evaluating core competencies and learning outcomes for training the next generation of sustainability researchers. Sustain Sci. https://doi.org/10.1007/s11625-019-00707-7

Soini K, Korhonen-Kurki K, Asikainen H (2019) Transactional learning and sustainability co-creation in a university—business collaboration. Int J Sustain High Educ 20:965-984. https://doi.org/10.1108/IJSHE-11-2018-0215 


\section{References}

Albareda Tiana S, Alférez Villarreal A (2016) A collaborative programme in sustainability and social responsibility. Int J Sustain High Educ 17:719-736. https://doi.org/10.1108/IJSHE -07-2016-0134

Álvarez-García O, Sureda-Negre J, Comas-Forgas R (2015) Environmental education in pre-service teacher training: a literature review of existing evidence. J Teach Educ Sustain 17:72-85. https ://doi.org/10.1515/jtes-2015-0006

Alvarez-García O, Sureda-Negre J, Comas-Forgas R (2018) Assessing environmental competencies of primary education pre-service teachers in Spain. Int J Sustain High Educ 19:15-31. https://doi. org/10.1108/IJSHE-12-2016-0227

Andrade HL (2019) A critical review of research on student selfassessment. Front Educ 4:1-13. https://doi.org/10.3389/feduc .2019 .00087

Arima A (2009) A plea for more education for sustainable development. Sustain Sci 4:3-5. https://doi.org/10.1007/s11625-009-0071-7

Ateskan A, Lane JF (2017) Assessing teachers' systems thinking skills during a professional development program in Turkey. J Clean Prod 172:4348-4356. https://doi.org/10.1016/j.jclep ro.2017.05.094

Azeiteiro UM, Bacelar-Nicolau P, Caetano FJPP, Caeiro S (2015) Education for sustainable development through e-learning in higher education: experiences from Portugal. J Clean Prod 106:308-319. https://doi.org/10.1016/j.jclepro.2014.11.056

Baggen Y, Kampen JK, Naia A et al (2017) Development and application of the opportunity identification competence assessment test (OICAT) in higher education. Innov Educ Teach Int 55:1-11. https ://doi.org/10.1080/14703297.2017.1348962

Barth M (2009) Assessment of key competencies-a conceptual framework. In: Adomßent M, Barth M, Beringer A (eds) World in Transition - Sustainability Perspectives for Higher Education, VAS Verlag, pp 93-100. https://ssrn.com/abstract=2170811

Barth M (2016) Teaching and learning in sustainability science. Sustain Sci. https://doi.org/10.1007/978-94-017-7242-6_27

Barth M, Michelsen G (2013) Learning for change: an educational contribution to sustainability science. Sustain Sci 8:103-119. https:// doi.org/10.1007/s11625-012-0181-5

Bernat CG, Segalàs Coral J, Hernández Gómez MA (2019) Assessment of sustainability competencies: a literature review and future pathways for ESD research and practice. Cent Eur Rev Econ Manag 3:19-44. https://doi.org/10.29015/cerem.664

Benninghaus J, Mühling A, Kremer K, Sprenger S (2019) Complexity in education for sustainable consumption - an educational data mining approach using mysteries. Sustainability 11:722. https:// doi.org/10.3390/su11030722

Besong F, Holland C (2015) The dispositions, abilities and behaviours (Dab) framework for profiling learners' sustainability competencies in higher education. J Teach Educ Sustain 17:5-22. https:// doi.org/10.1515/jtes-2015-0001

Biggs J (1996) Enhancing teaching through constructive alignment. High Educ 32:347-364. https://doi.org/10.1007/BF00138871

Bishop PA, Herron RL (2015) Use and misuse of the likert item responses and other ordinal measures. Int J Exerc Sci 8:297-302

Bögeholz S, Böhm M, Eggert S, Barkmann J (2014) Education for sustainable development in german science education: past-present-future. Eurasia J Math Sci Technol Educ 10:231-248. https ://doi.org/10.12973/eurasia.2014.1079a

Böhm M, Eggert S, Barkmann J, Bögeholz S (2016) Evaluating sustainable development solutions quantitatively: competence modelling for GCE and ESD. Citizensh Soc Econ Educ 15:190-211. https://doi.org/10.1177/2047173417695274
Božić M (2016) Competence development in a project and problem based learning professional practice module in engineering education based on ill-structured problem. ddd.uab.cat

Brandt J-O, Bürgener L, Barth M, Redman A (2019) Becoming a competent teacher in education for sustainable development. Int J Sustain High Educ 20:630-653. https://doi.org/10.1108/IJSHE $-10-2018-0183$

Brundiers K, Wiek A, Redman CL (2010) Real-world learning opportunities in sustainability: from classroom into the real world. Int J Sustain High Educ 11:308-324. https://doi.org/10.1108/14676 371011077540

Brundiers K, Barth M, Bernat GC, et al (2020) Key Competencies in sustainability in higher education - towards an agreed-upon reference framework. Sustain Sci. https://doi.org/10.1007/s1162 $5-020-00838-2$

Cabral C, Lochan Dhar R (2019) Green competencies: construct development and measurement validation. J Clean Prod 235:887-900. https://doi.org/10.1016/j.jclepro.2019.07.014

Cebrián G, Pascual D, Moraleda Á (2019) Perception of sustainability competencies amongst Spanish pre-service secondary school teachers. Int J Sustain High Educ 20:1171-1190. https://doi. org/10.1108/IJSHE-10-2018-0168

Cebrián Bernat G, Segalàs Coral J, Hernández Gómez MA (2019) Assessment of sustainability competencies: a literature review and future pathways for ESD research and practice. Cent Eur Rev Econ Manag 3:19-44. https://doi.org/10.29015/cerem.664

Charatsari C, Lioutas ED (2019) Is current agronomy ready to promote sustainable agriculture? Identifying key skills and competencies needed. Int J Sustain Dev World Ecol 26:232-241. https://doi. org/10.1080/13504509.2018.1536683

Clevenger CM, Ozbek ME (2013) Service-learning assessment: sustainability competencies in construction education. J Constr Eng Manag 139:A4013010. https://doi.org/10.1061/(ASCE)CO.19437862.0000769

Connell KH, Remington S, Armstrong C (2012) Assessing systems thinking skills in two undergraduate sustainability courses: a comparison of teaching strategies. J Sustain Educ 3

Crick RD (2008) Key competencies for education in a European context: narratives of accountability or care. Eur Educ Res J 7:311318. https://doi.org/10.2304/eerj.2008.7.3.311

Eggert S, Bögeholz S (2009) Students' use of decision-making strategies with regard to socioscientific issues: an application of the rasch partial credit model. Sci Educ 94:230-258. https://doi. org $/ 10.1002 /$ sce. 20358

Faham E, Rezvanfar A, Movahed Mohammadi SH, Rajabi Nohooji M (2017) Using system dynamics to develop education for sustainable development in higher education with the emphasis on the sustainability competencies of students. Technol Forecast Soc Change 123:307-326. https://doi.org/10.1016/j.techf ore.2016.03.023

Fallows S, Steven C (2000) Building employability skills into the higher education curriculum: a university-wide initiative. Educ. + Train

Fang X, Zhou B, Tu X et al (2018) What kind of a science is sustainability science? An evidence-based reexamination. Sustainability 10:1478. https://doi.org/10.3390/su10051478

Fink A (2014) Conducting research literature reviews: from the internet to paper. SAGE Publications

Foley RW, Archambault LM, Hale AE, Dong H-K (2017) Learning outcomes in sustainability education among future elementary school teachers. J Educ Sustain Dev 11:33-51. https://doi. org/10.1177/0973408217725861

Franco I, Saito O, Vaughter P et al (2019) Higher education for sustainable development: actioning the global goals in policy, curriculum and practice. Sustain Sci 14:1621-1642. https://doi.org/10.1007/ s11625-018-0628-4 
Frey A, Hartig J (2009) Assessment of competencies. Stud Educ Eval 35:55-56. https://doi.org/10.1016/j.stueduc.2009.10.001

Frisk E, Larson KL (2011) Educating for sustainability: competencies and practices for transformative action. J Sustain Educ 2:1-20

Fuertes-Camacho M, Graell-Martín M, Fuentes-Loss M, BalaguerFàbregas M (2019) Integrating sustainability into higher education curricula through the project method, a global learning strategy. Sustainability 11:767. https://doi.org/10.3390/su11030767

Galt RE, Parr D, Jagannath J (2013) Facilitating competency development in sustainable agriculture and food systems education: a self-assessment approach. Int J Agric Sustain 11:69-88. https:// doi.org/10.1080/14735903.2012.683569

Gardiner S, Rieckmann M (2015) Pedagogies of preparedness: use of reflective journals in the operationalisation and development of anticipatory competence. Sustainability 7:10554-10575. https:// doi.org/10.3390/su70810554

Garrecht C, Bruckermann T, Harms U (2018) Students' decisionmaking in education for sustainability-related extracurricular activities - a systematic review of empirical studies. Sustainability 10:3876. https://doi.org/10.3390/su10113876

Gordon S, Thomas I (2018) 'The learning sticks': reflections on a case study of role-playing for sustainability. Environ Educ Res 24:172190. https://doi.org/10.1080/13504622.2016.1190959

Gordon IJ, Bawa K, Bammer G et al (2019) Forging future organizational leaders for sustainability science. Nat Sustain 2:647-649. https://doi.org/10.1038/s41893-019-0357-4

Grosseck G, Țîru LG, Bran RA (2019) Education for sustainable development: evolution and perspectives: a bibliometric review of research, 1992-2018. Sustainability 11:6136. https://doi. org/10.3390/su11216136

Habron G (2012) Competency-based sustainability specialization at Michigan State University. Sustain J Rec 5:379-385. https://doi. org/10.1089/SUS.2012.9912

Habron G (2015) Integrating ePortfolios into sustainability education. Int J ePortfolio 5:123-134

Halberstadt J, Timm J-M, Kraus S, Gundolf K (2019) Skills and knowledge management in higher education: how service learning can contribute to social entrepreneurial competence development. J Knowl Manag 23:1925-1948. https://doi.org/10.1108/ JKM-12-2018-0744

Hallinger P, Chatpinyakoop C (2019) A bibliometric review of research on higher education for sustainable development, 1998-2018. Sustainability 11:2401. https://doi.org/10.3390/su11082401

Hartig J, Klieme E, Leutner D (2007) Assessment of competencies in educational contexts. Hogrefe \& Huber Publishers, Cambridge MA

Holdsworth S, Thomas I, Sandri O (2018) Assessing graduate sustainability attributes using a vignette/scenario approach. J Educ Sustain Dev 12:120-139. https://doi.org/10.1177/0973408218792127

Holdsworth S, Sandri O, Thomas I et al (2019a) The assessment of graduate sustainability attributes in the workplace: Potential advantages of using the theory of planned behaviour (TPB). J Clean Prod 238:117929. https://doi.org/10.1016/j.jclep ro.2019.117929

Holdsworth S, Sandri O, Thomas I et al (2019b) The use of the theory of planned behaviour to assess graduate attributes for sustainability. Environ Educ Res. https://doi.org/10.1080/13504 622.2019 .1700218

Kanbar N (2012) Can education for sustainable development address challenges in the Arab region? Examining business students' attitudes and competences on education for sustainable development: a case study. Discourse Commun Sustain Educ 3:41-62. https:// doi.org/10.2478/v10230-012-0003-0

Khaled AE, Gulikers JTM, Tobi H et al (2014) Exploring the validity and robustness of a competency self-report instrument for vocational and higher competence-based education. J Psychoeduc Assess 32:429-440. https://doi.org/10.1177/0734282914523913

Konrad T, Wiek A, Barth M (2020) Embracing conflicts for interpersonal competence development in project-based sustainability courses. Int J Sustain High Educ 21:76-96. https://doi. org/10.1108/IJSHE-06-2019-0190

Kricsfalusy V, George C, Reed MG (2018) Integrating problem- and project-based learning opportunities: assessing outcomes of a field course in environment and sustainability. Environ Educ Res 24:593-610. https://doi.org/10.1080/13504622.2016.1269874

Kuh GD, Jankowski N, Ikenberry SO, Kinzie JL (2014) Knowing what students know and can do: the current state of student learning outcomes assessment in US Colleges and Universities. learningoutcomesassessment.org

Lans T, Blok V, Wesselink R (2014) Learning apart and together: towards an integrated competence framework for sustainable entrepreneurship in higher education. J Clean Prod 62:37-47. https://doi.org/10.1016/j.jclepro.2013.03.036

Leutner D, Fleischer J, Grünkorn J, Klieme E (2017) Competence assessment in education: research, models and instruments. Springer International Publishing, Cham

Lockyer J, Carraccio C, Chan MK et al (2017) Core principles of assessment in competency-based medical education. Med Teach 39:609-616. https://doi.org/10.1080/0142159X.2017.1315082

Maak T, Pless NM (2006) Responsible leadership in a stakeholder society-a relational perspective. J Bus Ethics 66:99-115. https ://doi.org/10.1007/s10551-006-9047-z

Mehren R, Rempfler A, Buchholz J et al (2018) System competence modelling: theoretical foundation and empirical validation of a model involving natural, social and human-environment systems. J Res Sci Teach 55:685-711. https://doi.org/10.1002/tea.21436

Metzler ET, Kurz L (2018) Assessment 2.0: An organic supplement to standard assessment procedure

Migliorini P, Lieblein G (2016) Facilitating transformation and competence development in sustainable agriculture university education: an experiential and action oriented approach. Sustainability 8:1-15. https://doi.org/10.3390/su8121243

Mindt L, Rieckmann M (2017) Developing competencies for sustainability-driven entrepreneurship in higher education: a literature review of teaching and learning methods. Teoría de la Educación Revista Interuniversitaria 29:129-159. https://doi.org/10.14201/ teoredu2017

Molderez I, Fonseca E (2018) The efficacy of real-world experiences and service learning for fostering competences for sustainable development in higher education. J Clean Prod 172:4397-4410. https://doi.org/10.1016/j.jclepro.2017.04.062

Nicolaou CT, Constantinou CP (2014) Assessment of the modeling competence: a systematic review and synthesis of empirical research. Educ Res Rev 13:52-73. https://doi.org/10.1016/j.edure v.2014.10.001

O’Byrne D, Dripps W, Nicholas KA (2015) Teaching and learning sustainability: an assessment of the curriculum content and structure of sustainability degree programs in higher education. Sustain Sci 10:43-59. https://doi.org/10.1007/s11625-014-0251-y

Osagie ER, Wesselink R, Blok V et al (2016) Individual competencies for corporate social responsibility: a literature and practice perspective. J Bus Ethics 135:233-252. https://doi.org/10.1007/ s10551-014-2469-0

Ploum L, Blok V, Lans T, Omta O (2018) Exploring the relation between individual moral antecedents and entrepreneurial opportunity recognition for sustainable development. J Clean Prod 172:1582-1591. https://doi.org/10.1016/j.jclepro.2017.10.296

Reckase MD (2017) A tale of two models: sources of confusion in achievement testing. ETS Res Rep Ser. https://doi.org/10.1002/ ets2.12171 
Remington-Doucette S, Musgrove S (2015) Variation in sustainability competency development according to age, gender, and disciplinary affiliation. Int J Sustain High Educ 16:537-575. https://doi. org/10.1108/IJSHE-01-2013-0005

Remington-Doucette SM, Hiller Connell KY, Armstrong CM, Musgrove SL (2013) Assessing sustainability education in a transdisciplinary undergraduate course focused on real-world problem solving. Int J Sustain High Educ 14:404-433. https://doi. org/10.1108/IJSHE-01-2012-0001

Roth C (1992) Environmental Literacy: Its Roots, Evolution and Directions in the 1990s. ERIC Clear Sci Math Environ Educ Columbus $\mathrm{OH}$

Salovaara JJ, Soini K, Pietikäinen J (2020) Sustainability science in education: analysis of master's programmes' curricula. Sustain Sci 15:901-915. https://doi.org/10.1007/s11625-019-00745-1

Sandri O, Holdsworth S, Thomas I (2018) Vignette question design for the assessment of graduate sustainability learning outcomes. Environ Educ Res 24:406-426. https://doi.org/10.1080/13504 622.2016.1263280

Savage E, Tapics T, Evarts J et al (2015) Experiential learning for sustainability leadership in higher education. Int J Sustain High Educ 16:692-705. https://doi.org/10.1108/IJSHE-10-2013-0132

Schuwirth LWT, Van Der Vleuten CPM (2011) Programmatic assessment: from assessment of learning to assessment for learning. Med Teach 33:478-485. https://doi.org/10.3109/01421 59X.2011.565828

Snyder H (2019) Literature review as a research methodology: an overview and guidelines. J Bus Res 104:333-339. https://doi. org/10.1016/j.jbusres.2019.07.039

Sroufe R, Sivasubramaniam N, Ramos D, Saiia D (2015) Aligning the PRME. J Manag Educ 39:244-275. https://doi.org/10.1177/10525 62914560795

Waltner E-M, Rieß W, Mischo C (2019) Development and validation of an instrument for measuring student sustainability competencies. Sustainability 11:1-20. https://doi.org/10.3390/su11061717

Wiek A, Withycombe L, Redman CL (2011) Key competencies in sustainability: a reference framework for academic program development. Sustain Sci 6:203-218. https://doi.org/10.1007/s1162 5-011-0132-6

Zlatkin-Troitschanskaia O, Shavelson RJ, Kuhn C (2015) The international state of research on measurement of competency in higher education. Stud High Educ 40:393-411. https://doi. org/10.1080/03075079.2015.1004241

Publisher's Note Springer Nature remains neutral with regard to jurisdictional claims in published maps and institutional affiliations. 